\title{
Inonotus crustosus (Basidiomycota, Polyporales), first record for the chilean mycobiota
}

\author{
Inonotus crustosus (Basidiomycota, Polyporales), nuevo registro para la micobiota \\ chilena
}

PABlo SANDOVAL-Leiva

Biota Gestión y Consultorías Ambientales Ltda., Miguel Claro 1224, Providencia, Santiago, Chile. agropablo@gmail.com

\begin{abstract}
RESUMEN
Se registra por primera vez para Chile la especie Inonotus crustosus (Speg.) J.E. Wright \& J.R. Deschamps (Hymenochaetaceae, Basidiomycota). Los basidiocarpos fueron encontrados desarrollándose sobre madera de Nothofagus antarctica, en dos puntos de la Región de Aisén. Se describen e ilustran los caracteres diagnósticos y se realizan comentarios acerca de las especie.
\end{abstract}

During two fungal surveys in the region of Aisén, Southern Chile, conspicuous fungal fructifications were observed growing on Nothofagus antarctica (ñirre) wood. Later, collections were identified as basidiomata of Inonotus crustosus (Speg.) J.E. Wright \& J.R. Deschamps (Hymenochaetaceae, Kirk et al. 2008), which previously was only known from Southern Argentina (Rajchenberg 2006). Basidiomata were processed following Ryvarden \& Gilberston (1993) and documented in situ and in laboratory by digital colour photographs with a Nikon D90 camera. Observations of microscopic characteristics were made on free hands sections of basidiomata, under a phase contrast microscope (Primo Star, Carl Zeiss, Germany), mounted on glass slides in water, $5 \%(\mathrm{w} / \mathrm{v}) \mathrm{KOH}$, Melzer's reagent, phloxine and cotton blue lactophenol. For preservation, specimens were desiccated for $48 \mathrm{~h}$ in a ventilated oven and deposited in the author's personal collection and in the fungal collection of the Natural History Museum Santiago, Chile (SGO).

\section{TAXONOMY}

Inonotus crustosus (Speg.) J.E. Wright \& J.R. Deschamps. Fl. Criptog. Tierra del Fuego 11(3): 22 (1975).

Synonyms:

Polyporus (Resupinatus) crustosus Speg., Bol. Acad. Nac. Cs. Córdoba 11: 64 (1887).

Phellinus crustosus (Speg.) Gottlieb, J.E. Wright \& Moncalvo, Mycol. Progress 1: 309 (2002).
Basidiocarp poroid, annual, resupinate, xanthocroic, up to $20 \times 7 \mathrm{~cm}$ (Fig. 1), with margins weakly attached to the substrate, pores 2-3(-4) $\mathrm{mm}$, decurrent, gray brown to reddish light brown; context thin, 0.5-1 mm thick, tubes up to $13 \mathrm{~mm}$ long, corky to fibrous when fresh and rigid and brittle when dry; hyphal system monomitic; generative hyphae simple-septate, up to $7.5 \mu \mathrm{m}$ diam., hyaline to light brown (Fig. 2d); basidia broadly clavate, 7-11 x 20-25 $\mu \mathrm{m}$, 4-spored, sterigmata up $5 \mu \mathrm{m}$ long. (Fig. 2b); basidiospores ellipsoid to obovoid, $8.3-11 \times 6.5-8 \mu \mathrm{m}$, with hyaline to light brown, thick walls, IKI- and cyanophilous (Fig. 2a); hymenial setae abundant, subulate to ventricose, straight to strongly curved, few clavate, 15-35(-48) x 8-12 $\mu \mathrm{m}$, thick walls [up $5.5 \mu \mathrm{m}$ thick], yellowish to reddish brown, incrusted or not at the apex (Fig. 2c).

Specimen examined: CHILE, Region of Aisén, within Nothofagus antarctica Forest near Lake Yulton. On dead stems and branches of Nothofagus antarctica, lat. 459'20.19'S, long. 7254'28.41'W, alt. 493 masl, 25VI-2008, leg. \& det. P. Sandoval-Leiva, PSL 160 (SGO 163550). Ibid. In Sphagnum bog near Turbio river; on dead stems of Nothofagus antarctica, lat. 45 6'49.79'S, long. 72¹4'12.05”W, alt., 500 masl, 27-VII-2011, leg. P. Sandoval-Leiva, P. Saldivia \& J. Martínez, det. P. SandovalLeiva, PSL 191 (SGO 163162).

Chilean collections of I. crustosus correspond well to morphological descriptions by Gottlieb et al. (2002), 


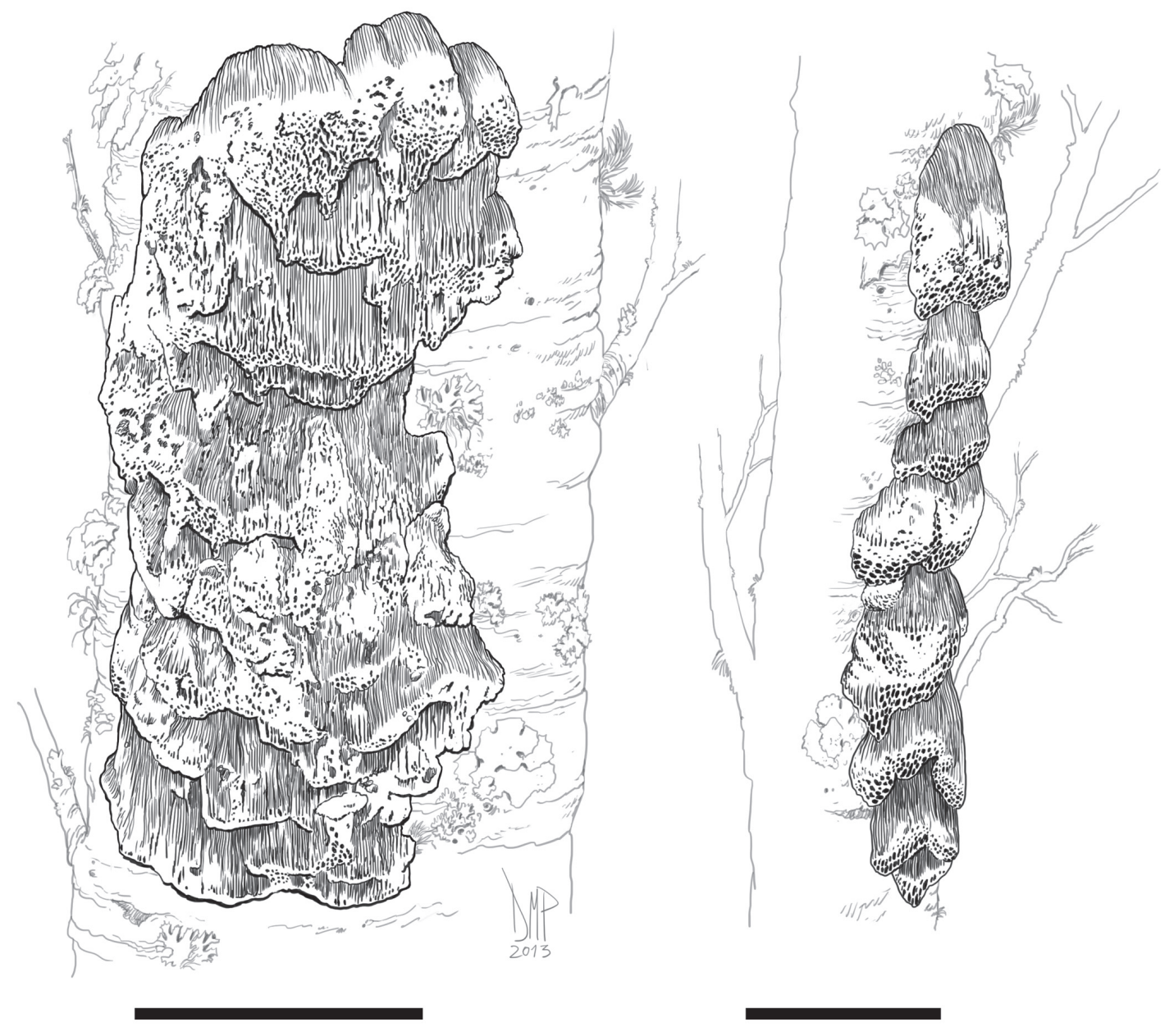

FIGURE 1. Inonotus crustosus (SGO 163162), basiodiomata growing on Nothofagus antarctica dead stems. Bars: $5 \mathrm{~cm}$ (Drawings by D. Martínez).

FigURA 1. Inonotus crustosus (SGO 163162), basidiocarpos desarrollándose sobre troncos muertos de Nothofagus antarctica. Barras: 5 cm (Dibujos por D. Martínez).

Rajchenberg (2006) and Wright \& Deschamps (1975). However, Chilean materials present some differences compared to the above-cited descriptions: at macroscopic level, the Chilean basidiomata are larger, apparently under good environmental conditions the basidiomata can continue advancing through the stem or branches of the host. In addition, decurrent pores reach a greater length. In terms of microscopical features, basidia were slightly shorter than described by Rajchenberg (2006), whereas cyanophilous spores were present, unlike findings by Wright \& Deschamps (1975), hymenial setae were longer than those observed by all other authors. Also, it is important to note that this is the first record of the species growing on wood of Nothofagus antarctica.

I. crustosus is an easily identifiable species, characterized by its resupinate basidiomata, large spores with thickened walls and the presence of hymenial setae occasionally apically incrustated. This taxon had previously been recorded only from Andean-Patagonian forests of Argentina between the provinces Chubut and Tierra del Fuego, the latter material having been described by Spegazzini (1887).

Gottlieb et al. (2002) suggested to transfer this taxon to the genus Phellinus, based on one hand on molecular data which showed that Argentinean specimens of I. crustosus do not share a recent common ancestor with Inonotus sensu stricto, on the other hand on the distinction of two types of generative hyphae. In this work, it is followed the conservative concept proposed by Rajchenberg (2006), maintaining the name Inonotus until there is a better comprehension of the relationships within the Hymenochaetales, adding to the fact that Chilean collections clearly show a monomitic hyphal system. 


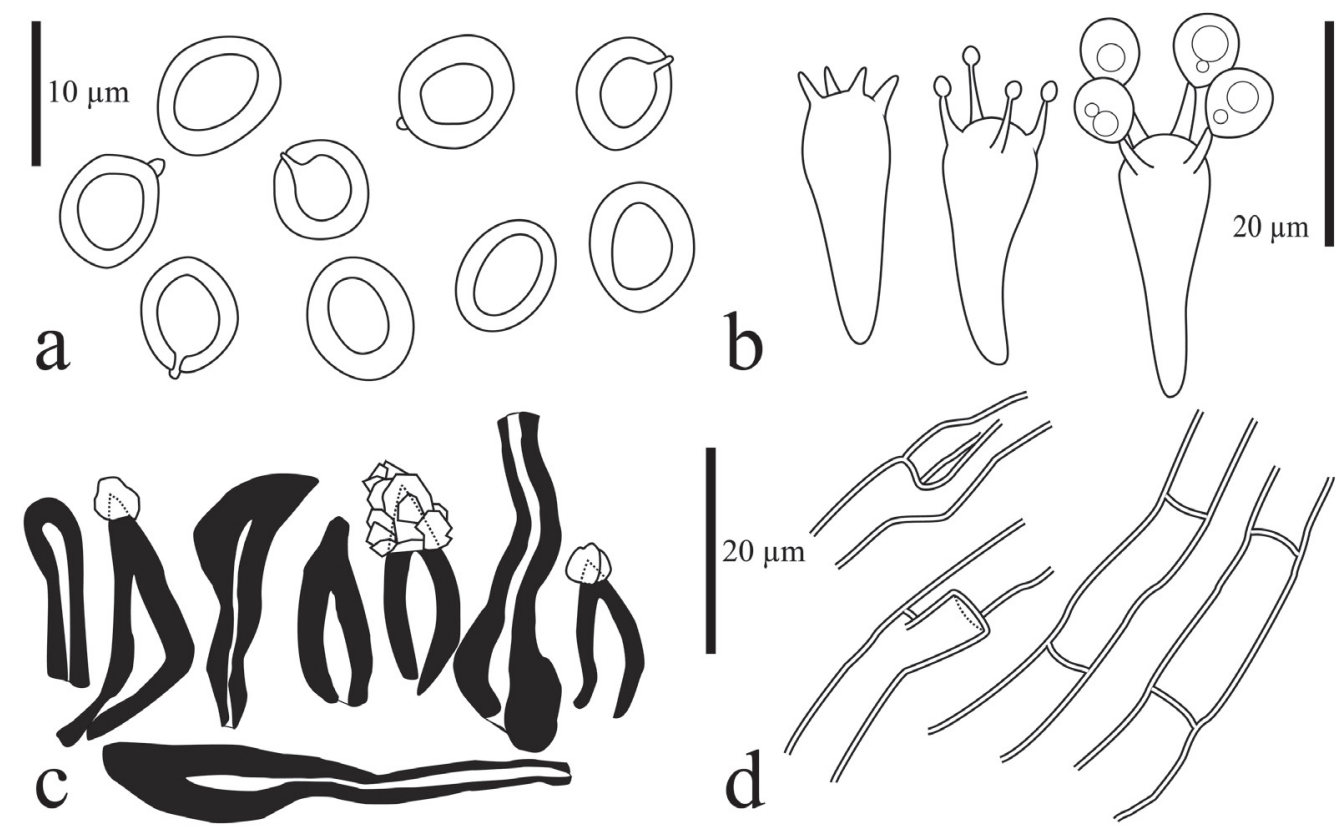

FIGURE 2. Inonotus crustosus (SGO 163162), microscopic characters: a: basidiospores, b: basidia, c: hymenial setae, d: generative hyphae (Drawings by P. Sandoval-Leiva).

FigURA 2. Inonotus crustosus (SGO 163162), caracteres microscópicos: a: basidiosporas, b: basidias, c: setas himeniales, d: hifas generativas (Dibujos por P. Sandoval-Leiva).

\section{REFERENCES}

Gottlieb, A.M., J.E. Wright \& J.M. Moncalvo. 2002. Inonotus s.l. in Argentina - morphology, cultural characters and molecular analyses. Mycological Progress 1(3): 299-313.

Kirk, P.M., P.F. Cannon, D.W. Minter \& J.A. Stalpers. 2008. Dictionary of the fungi. 10th Edition. CAB International, Wallingford. $771 \mathrm{pp}$.

Rajchenberg, M. 2006. Los Políporos (Basidiomycetes) de los Bosques Andino-Patagónicos de Argentina. Bibliotheca Mycologica, 201. J Cramer, Berlin-Stuttgart. 300 pp.
Ryvarden, L. \& R.L. Gilbertson. 1993. European Polypores part 1. Abortiporus - Lindtneria. Synopsis Fungorum 6.Fungiflora, Oslo. 387 pp.

Spegazzini, C. 1887. Fungi Fuegiani. Boletín de la Academia Nacional de Ciencias de Córdoba 11: 135-308.

Wright, J.E. \& J.R. Deschamps. 1975. Orden Aphyllophorales, Fistulinaceae, Mucronoporaceae, Polyporaceae. In: S.A. Guarrera, I. Gamundí de Amos \& D. Rabinovich de Halperin (Eds.) Flora Criptogámica de Tierra del Fuego 11 (3). Buenos Aires, Argentina: Fondo para la Educación, la Ciencia y la Cultura (FECIC), 62 pp.

Recibido: 25.10 .13

Aceptado: 05.03.14 